\title{
Directions and Trends of Mathematical Education Research in Indonesia
}

\author{
RH Simanungkalit ${ }^{1}$, Kartono $^{2}$, SB Waluya ${ }^{3}$, Rochmad $^{4}$, Isnarto $^{5}$ \\ \{ricksimanungkalit@uhn.ac.id, hunter.rick89@yahoo.com \}

\begin{abstract}
Mathematics Education, Postgraduate, Universitas Negeri Semarang, Semarang, Central Java, 50229, Indonesia ${ }^{1,2,3,4,5}$

FMIPA, Universitas HKBP Nommensen, Medan, North Sumatera, 20234, Indonesia ${ }^{1}$
\end{abstract}

\begin{abstract}
Mathematics education research has undergone very rapid changes, marked by the formation of many mathematics education research organizations and the availability of accredited and indexed research publications. The purpose of this study was to see a description of past and present research and to determine the direction and trends of future mathematics education research. This research is a literature study by examining 106 articles that have been published in the Journal on Mathematics Education (JMESriwijaya Univ.) 2010-2017, then analyzed using descriptive analysis method. Past mathematics education research has been dominated by the issue of mathematics learning model / theory / curriculum design with a focus on primary education students as research subjects. Currently the research topic of mathematics education examines the media and learning technology with a study into the high-level thinking processes of students with an even subject. Future mathematics education research will also examine higher-order thinking skills which emphasize 4C (Four Cs: Creativity, Critical Thinking, Communication, and Collaboration) abilities.
\end{abstract}

Keywords: Mathematics Education Research Trends, Research Topics, Research Subjects.

\section{Introduction}

Mathematics education research is needed to help solve mathematics learning problems and provide new efforts and breakthroughs in developing mathematics education and learning. About research activities in mathematics education, this paper will describe the past, present, and future profile of mathematics education research to find out the trends and issues it has studied, especially in the past (2010-2014). A trend that is currently developing in 2014- 2017 (the last three years) and an overview of future mathematics education research trends. The purpose of this study was to see a description of past and present research and to determine the direction and trends of future mathematics education research. It is hoped that this article can be a reference for researchers who will carry out research in the field of mathematics education, to get an overview of the direction and trends of the research. 


\section{Method}

This research is a literature review by examining 106 articles that have been published in the Journal on Mathematics Education (JME-Sriwijaya Univ.) 2010-2017. The type of data in this study is in the form of secondary data obtained from the Journal on Mathematics Education (JME-Sriwijaya Univ.). The data that has been obtained are then analyzed using descriptive analysis methods. Descriptive analysis method is carried out by describing the facts which is then followed by a more in-depth analysis.

\section{Results and Discussion}

Mathematics education research is currently developing very fast; this can be seen from the many mathematics education research organizations such as the International Congress for Mathematics Instruction (ICMI), the International Group for Psychological Mathematics Education (IGPME), European Researchers of Mathematics Education (ERME), and so on. Furthermore, the results of mathematics education research are also disseminated through mathematics education seminars and conferences, such as the International Conference in Mathematics Education (ICME), the Conference of the European Research in Mathematics Education (CERME). In Indonesia, there is the National Mathematics Education Conference (KNPM). Apart from seminars and conferences, dissemination of research results is also carried out through journals, both in print and electronic (online), such as the Journal for Research in Mathematics Education (JRME), the Journal of Mathematics Teacher Education (JMTE) and in Indonesia has the IndoMS Journal of Mathematics Education (IndoMS JME), Journal on Mathematics Education (JME-Univ. Sriwijaya) and the National Journal of Mathematics Education (JNPM) which has been accredited by Dikti and DOAJ.

This paper tries to identify, describe, and discuss the profile of mathematics education research in the Mathematics Education Journal in Indonesia, with three discussion references, namely: (1) General topics/issues and problems under study, (2) who is the subject of investigation, (3) what approaches, and methods are used concerning the research problem.

\subsection{Past Mathematics Education Research Trends}

In past mathematics education research (2010-2014) in the Journal on Mathematics Education (JME-Sriwijaya Univ.) Can be seen in Table 1.Table 1 provides an overview of general topics/issues of problems that were studied by researchers from 2010 to the year 2014 . Several researchers such as [1], [2], [3], [4] studied Problem Solving Ability, while research on the topic of Creative Thinking was conducted by [5], [6].

Research conducted by [7], [8], [9], [10] chose the topic of design or developing a Model/theory/Curriculum. Meanwhile, studies on metacognition and spatial abilities have been studied by [11], [4]. Several researchers such as [12], [13], [14], [15] have reviewed 
TIMSS and PISA. Meanwhile, research conducted by [16], [17], [5] examines topics regarding contextual problems and Realistic Mathematics.

Table 1. Topics Studies of Past Mathematics Education Research

\begin{tabular}{clc}
\hline Nu & \multicolumn{1}{c}{ Topics Studies } & Sum \\
\hline 1 & Model / Curriculum Design & 15 \\
2 & Contekstual Problem / RME & 9 \\
3 & PISA / TIMSS & 6 \\
4 & Metacognition / Spasial & 4 \\
5 & Problem Solving & 4 \\
6 & Creative Thinking & 3 \\
\hline
\end{tabular}

From table 1. It can be seen that mathematics education research was dominated by the design of mathematics models/theories/curricula. The use of the mathematics learning model with the concept of a game dominates in past research. Judging from the research subject, mathematics education research used to take research subjects on elementary school students. Table 2 shows a recapitulation of the first mathematics education research subjects. It can be said that the first mathematics education research subjects focused on elementary education students. Only a small proportion of researchers take research subjects in secondary and tertiary education.

Table 2. The subject of Past Mathematics Education Research

\begin{tabular}{clc}
\hline Nu & \multicolumn{1}{c}{ Subject Research } & Sum \\
\hline 1 & Elementary school students & 25 \\
2 & Junior High School Students & 8 \\
3 & High School Students & 1 \\
4 & College student & 2 \\
5 & Teacher & 0 \\
\hline
\end{tabular}

In the past, the research method for mathematics education used a qualitative approach. This type of qualitative approach is generally used in analytical research, such as research by [18], [19], [20], etc.

Table 3. Research Approaches in Mathematics Education in the Past

\begin{tabular}{clc}
\hline $\mathbf{N u}$ & \multicolumn{1}{c}{ Kind of Approaches } & Sum \\
\hline 1 & Quantitative Approaches & 18 \\
2 & Qualitative Approaches & 21 \\
\hline
\end{tabular}

\subsection{Current Trend of Mathematics Education Research}

In current mathematics education research (the last three years) in the Journal on Mathematics Education (JME-Sriwijaya Univ.) It can be seen in Table 4. Table 4 provides an 
overview of general topics/issues of researchers' problems from 2014 to 2017. Some researchers such as [21], examined problem-solving abilities. The ability to think creatively was studied by [22], [23], [24], [25].

[26] reviewed the topic of model/curriculum design; while studied topics/issues regarding Mathematical Literacy or PISA / TIMSS reviewed [27], [28], [29], [30] and [31]. The topic of contextual issues / RME was reviewed by [32], [33], [34], [35], and in mathematics education research in the last three years have studied a lot of mathematics learning technology/media including [36], [37], [38], [39], [40].

Table 4. Topics Studies of Current Mathematics Education Research

\begin{tabular}{clc}
\hline Nu & \multicolumn{1}{c}{ Topics Studies } & Sum \\
\hline 1 & Technology / Media & 14 \\
2 & PISA / TIMSS & 9 \\
3 & Creative Thinking & 7 \\
4 & Contextual Problem/RME & 4 \\
5 & Problem Solving & 4 \\
6 & Model/Curriculum Design & 2 \\
\hline
\end{tabular}

Judging from the research subjects, mathematics education research now tends to be balanced in choosing research subjects at the primary and secondary education levels. Table 5 shows a recapitulation of the first mathematics education research subjects. What is interesting in the research of mathematics education in the last three years is selecting teachers as the subject of mathematics education research. This indicates that it can be said that the quality and professionalism of teachers also influence the quality of education in Indonesia. This is in line with [41], [42] by 2030, all governments ensure that all learners are taught by qualified, professionally trained, motivated and well-supported teachers".

Table. 5. Subject of Current Mathematics Education Research

\begin{tabular}{clc}
\hline $\mathbf{N u}$ & \multicolumn{1}{c}{ Subject Research } & Sum \\
\hline 1 & Elementary school students & 5 \\
2 & Junior High School Students & 10 \\
3 & High School Students & 10 \\
4 & College student & 5 \\
5 & Teacher & 10 \\
\hline
\end{tabular}

Research methods in mathematics education research now use a more quantitative approach. This quantitative approach is generally used in an experimental study by applying new techniques or new learning technologies. 
Table. 6. Research Approaches in Currently Mathematics Education

\begin{tabular}{clc}
\hline Nu & \multicolumn{1}{c}{ Kind of Approaches } & Sum \\
\hline 1 & Quantitative Approaches & 26 \\
2 & Qualitative Approaches & 15 \\
\hline
\end{tabular}

\subsection{Future Mathematics Education Research Trends}

Future research trends in mathematics education will be influenced by developments in science and technology globally. Students must compete in a global society in the current information age so that students are required to have Creativity, critical thinking skills, communication, and collaboration, which is better known as the acronym 'Four Cs' [43], [44]. Through educators, schools must be able to complete 4C (Four Cs) skills to prepare their students as responsive and able to face global competition. Students will also dominate research subjects in mathematics education research in the future at the primary education level. This is consistent with the thought that when students are at the elementary level, it is the best time to develop their understanding and thinking about mathematics. Mathematical literacy is still a significant challenge in primary mathematics education. Mathematical literacy for all young people is the goal, and the fundamental priority of mathematics taught during primary education [45]. This is because Indonesia's achievements in the PISA and TIMSS assessments are still far from expected.

Meanwhile, [46] conveyed the three most significant challenges in mathematics education: mathematics, the role of mathematics in society (the part of mathematics in society), and equality in mathematics education. [44] says that math work is about problemsolving, reasoning, curiosity, joy, and not just following procedures to get answers; the role of mathematics in society is meant that all groups must achieve the need to see mathematics is a daily human activity, while equality in mathematics education is intended for all The targets in mathematics education, no one should be left behind. This is in line with the Incheon Declaration, which states that inclusion and equity in and through education is the cornerstone of a transformative education agenda [47].

\section{Conclusion}

The trend of mathematics education research develops, along with the development of science and technology. The direction of mathematics education research is in line with new findings in mathematics education. Past research on mathematics education, which was dominated by curriculum design/models, included learning theory changing towards mathematics learning technology/media and research on students' higher-order thinking processes. Future research in mathematics education will also examine higher-order thinking skills and emphasize the 4-C (four Cs) ability. This is due to the demands of globalization needs today for students' abilities. The subject of mathematics education research is currently more developed than that of mathematics education in the past. Where in current mathematics education research, teachers become new research subjects, which will also be in line with the 
trends in mathematics education research in the future. Types of mathematics education research approaches will also develop over time. In the past, mathematics education was dominated by qualitative methods. In contrast, current research is dominated by quantitative techniques. Future research in mathematics education provides a more significant opportunity to use qualitative and quantitative research types (mixed method).

\section{References}

[1] Sugiman, Kusumah Y. 2010. Dampak Pendidikan Matematika Realistik Terhadap Peningkatan Kemampuan Pemecahan Masalah Siswa Smp. Jurnal on Mathematics Education Universitas sriwijaya: Vol 1, No 1, pp. 41-52.

[2] Yuli T, Siswono E. 2010. Leveling Students' Creative Thinking In Solving And Posing Mathematical Problem. Journal on Mathematics Education Universitas Sriwijaya: Vol 1, No 1, pp. 17-40.

[3] Surya E, Sabandar J, Kusumah Y S, Darhim. 2013. Improving Junior High School Visual Thinking Representation Ability in Mathematical Problem Solving by CTL. Journal on Mathematics Education Universitas Sriwijaya: Vol 4, No 1, pp. 113-126.

[4] Murni A, Sabandar J, Kusumah Y S, Kartasamita B G. 2013. The Enhancement Of Junior High School Students' Abilities In Mathematical Problem Solving Using Soft Skill-Based Metacognitive Learning. Journal on Mathematics Education Universitas Sriwijaya: Vol 4, No 2, pp. 194-203.

[5] Palinussa A L. 2013). Students' Critical Mathematical Thinking Skills and Character: Experiments for Junior High School Students through Realistic Mathematics Education Culture-Based. Journal on Mathematics Education Universitas Sriwijaya: Vol 4, No 1, pp. 75-94.

[6] Qohar A, Sumarmo U. 2013. Improving Mathematical Communication Ability and Self Regulation Learning Of Yunior High Students by Using Reciprocal Teaching. Journal on Mathematics Education Universitas Sriwijaya: Vol 4, No 1, pp. 59-74.

[7] Yee L P. 2010. Designing A Mathematics Curriculum. Journal on Mathematics Education Universitas Sriwijaya: Vol 1, No 1, pp. 1-10.

[8] Helsa Y, Hartono Y. 2011. Designing Reflection and Symmetry Learning by Using Math Traditional Dance in Primary School. Journal on Mathematics Education Universitas Sriwijaya: Vol 2, No 2, pp. 79-94.

[9] Murdiyani N M, Zulkardi, Ilma R, Galen F, Eerde D. 2013. Developing a Model to Support Students in Solving Subtraction. Journal on Mathematics Education Universitas Sriwijaya: Vol 4, No 1, pp. 95-112.

[10] Kaune C, Nowinska E, Paetau A, Griep M. 2013. Games for Enhancing Sustainability of Year 7 Maths Classes in Indonesia: Theory-Driven Development, Testing, and Analyses of Lessons, and of Students' Outcomes. Journal on Mathematics Education Universitas Sriwijaya: Vol 4, No 2, pp. 129-150.

[11] Kaune C, Fresenborg E C, Nowinska E, Marpaung Y, Handayani N. 2012. Developing Metacognitive and Discursive Activities in The Indonesian Mathematics Education. Journal on Mathematics Education Universitas Sriwijaya: Vol 3, No 1, pp. 1-16.

[12] Stacey, K., 2011. The PISA View of Mathematical Literacy in Indonesia. Journal on Mathematics Education Universitas Sriwijaya: Vol 2, No 2, pp. 95-126. 
[13] Novita R, Zulkardi, Hartono Y. 2012. Exploring Primary Student's Problem-Solving Ability By Doing Tasks Like Pisa's Question. Journal on Mathematics Education Universitas Sriwijaya: Vol 3, No 2, pp. 133-150.

[14] Edo S I, Ilma R, Hartono Y. 2013. Investigating Secondary School Students' Difficulties in Modeling Problems PISA-Model Level 5 And 6. Journal on Mathematics Education Universitas Sriwijaya: Vol 4, No 1, pp. 41-58.

[15] Ayhan S, Zulkardi, Darmawijoyo. 2014. Developing Mathematics Problems Based On Pisa Level Of Change And Relationships Content. Journal on Mathematics Education Universitas Sriwijaya: Vol 5, No 1, pp. 47-56.

[16] Kairuddin, Darmawijoyo. 2011. The Indonesian's Road Transportations as The Contexts to Support Primary School Students Learning Number Operation. Journal on Mathematics Education Universitas Sriwijaya: Vol 2, No 1, pp. 67-78.

[17] Anwar L, Budayasa I K, Amin SM, Haan D. 2012. Eliciting Mathematical Thinking of Students through Realistic Mathematics Education. Journal on Mathematics Education Universitas Sriwijaya: Vol 3, No 1, pp. 55-70.

[18] Pramudiani P, Zulkardi, Hartono Y, Amerom B. 2011. A Concrete Situation For Learning Decimals. Journal on Mathematics Education Universitas Sriwijaya: Vol 2, No 2, pp. 215-230.

[19] Yuberta K R, Zulkardi, Hartono Y, Galen F. 2011. Developing Student's Notion Of Measurement Unit For Area. Journal on Mathematics Education Universitas Sriwijaya: Vol 2, No 2, pp. 173 184.

[20] Khikmiyah F, Lukito A, Patahudin S M. 2012. Students' Modelling in Learning The Concept of Speed. Jurnal on Mathematics Education Universitas sriwijaya: Vol 3, No 1, pp. 87-98.

[21] Rasiman. 2015. Leveling Of Critical Thinking Abilities Of Students Of Mathematics Education In Mathematical Problem Solving. Journal on Mathematics Education Universitas Sriwijaya: Vol 6, No 1, pp. 40-52.

[22] Kurniati, Kusumah Y S, Sabandar J, Herman T. 2015. Mathematical Critical Thinking Ability Through Contextual Teaching And Learning Approach. Journal on Mathematics Education Universitas Sriwijaya: Vol 6, No 1, pp. 53-62.

[23] Widyatiningtyas R, Kusumah Y S, Sumarmo U, Sabandar J. 2015. The Impact Of Problem-Based Learning Approach To Senior High School Students' Mathematics Critical Thinking Ability. Journal on Mathematics Education Universitas Sriwijaya: Vol 6, No 2, pp. 107-116.

[24] Fatah A, Suryadi D, Sabandar J, Turmudi. 2016. Open-Ended Approach: An Effort In Cultivating Students' Mathematical Creative Thinking Ability And Self-Esteem In Mathematics. Journal on Mathematics Education Universitas Sriwijaya: Vol 7, No 1, pp. 9-18.

[25] Kadir, Luciana, Satriawati G. 2017. The Implementation Of Open-Inquiry Approach To Improve Students' Learning Activities, Responses, And Mathematical Creative Thinking Skills. Journal on Mathematics Education Universitas Sriwijaya: Vol 8, No 1, pp. 103-114.

[26] Ekawati R, Lin F L. 2014. Designing Teacher Professional Development For Mathematics Teaching With Variation Theory. Journal on Mathematics Education Universitas Sriwijaya: Vol 5, No 2, pp. 127-137.

[27] Dewantara A H, Zulkardi, Darmawijoyo. 2015. Assessing Seventh Graders' Mathematical Literacy In Solving Pisa-Like Tasks. Journal on Mathematics Education Universitas Sriwijaya: Vol 6, No 2, pp. 117-128.

[28] Lowrie T, Patahuddin S M. 2015. El Pisa As A Lesson Design Framework. Jurnal on Mathematics Education Universitas sriwijaya: Vol 6, No 2, pp. 77-92. 
[29] Novita R, Putra M. 2016. Using Task Like Pisa's Problem To Support Student's Creativity In Mathematics. Journal on Mathematics Education Universitas Sriwijaya: Vol 7, No 1, pp. 31-42.

[30] Oktiningrum W, Zulkardi, Hartono Y. 2016. Developing Pisa-Like Mathematics Task With Indonesia Natural And Cultural Heritage As Context To Assess Students Mathematical Literacy. Journal on Mathematics Education Universitas Sriwijaya: Vol 7, No 1, pp. 1-8.

[31] Wijaya, A., 2016. Students' Information Literacy: A Perspective from Mathematical Literacy. Journal on Mathematics Education Universitas Sriwijaya: Vol 7, No 2, pp. 73-82.

[32] Julie H, Suwarsono, Juniata D. 2014. Understanding Profile From The Philosophy, Principles, And Characteristics Of RME. Journal on Mathematics Education Universitas Sriwijaya: Vol 5, No 2, pp. 148-159.

[33] Lestariningsih, Anwar M, Setiawan A M. 2015. Investigating The Act Of Design In Discharge Concept Using PMRI. Jurnal on Mathematics Education Universitas sriwijaya: Vol 6, No 2, pp. 129-138.

[34] Surya E, Putri F A, Mukhtar. 2017. Improving Mathematical Problem-Solving Ability And SelfConfidence Of High School Students Through Contextual Learning Model. Journal on Mathematics Education Universitas Sriwijaya: Vol 8, No 1, pp. 85-94.

[35] Dündar S, Gündüz N. 2017. Justification For The Subject Of Congruence And Similarity In The Context Of Daily Life And Conceptual Knowledge. Journal on Mathematics Education Universitas Sriwijaya: Vol 8, No 1, pp. 35-54.

[36] Saadati F, Tarmizi R A, Ayub. 2014 A M. Utilization Of Information And Communication Technologies In Mathematics Learning. Journal on Mathematics Education Universitas Sriwijaya: Vol 5, No 2, pp. 138-147.

[37] Loong E Y K. 2014. Using The Internet In High School Mathematics. Journal on Mathematics Education Universitas Sriwijaya: Vol 5, No 2, pp. 108-126.

[38] Oktaviyanthi R, Supriani Y. 2015. Utilizing Microsoft Mathematics In Teaching And Learning Calculus. Journal on Mathematics Education Universitas Sriwijaya: Vol 6, No 1, pp. 63-76.

[39] Saraswati S, Ilma R, Somakim. 2016. Supporting Students' Understanding Of Linear Equations With One Variable Using Algebra Tiles. Journal on Mathematics Education Universitas Sriwijaya: Vol 7, No 1, pp. 19-30.

[40] Aris R M, Ilma R, Susanti E. 2017. Design Study: Integer Subtraction Operation Teaching Learning Using Multimedia In Primary School. Journal on Mathematics Education Universitas Sriwijaya: Vol 8, No 1, pp. 95-102.

[41] Conway PF, dan Sloane F C. 2006. International Trends in Post-Primary Mathematics Education: Perspectives on Learning, Teaching and Assessment, Dublin: NCCA.

[42] Unesco. 2014. UNESCO Education Strategy, 2014 - 2021. Paris: Unesco.

[43] NEA. 2011. Preparing 21st Century Students for a Global Society: An Educator's Guide to the "Four Cs," Washington: NEA.

[44] Murtiyasa B. 2016. Isu-Isu Kunci Dan Tren Penelitian Pendidikan Matematika. Konferensi Nasional Penelitian Matematika dan Pembelajarannya (KNPMP I): Universitas Muhammadiyah Surakarta.

[45] Unesco. 2012. Challenges in primary mathematics education. Paris: Unesco.

[46] Stephan M L, Fish M C, Chval K B, Eisenmann H, Wanko, Konold, Civil dan Wilkerson. "Grand Challenges and Opportunities in Mathematics Education Research". Journal for Research in Mathematics Education Volume 46 No. 2 March 2015, pp. 134 - 146.

[47] World Education Forum, 2015. Education 2030: Towards inclusive and Equitable quality education and lifelong learning for all, Paris: Unesco. 